\title{
Petani Jeruk di Bumi Tanadoang 1979-2017
}

\author{
Muh. Nur Fajri Ramadhana M.K, Ahmadin, Muhammad Saleh Madjid \\ Jurusan Pendidikan Sejarah FIS UNM \\ Muhammadnurfajri1996@gmail.com
}

\begin{abstract}
Abstrak
Tulisan ini mencoba untuk memberikan penjelasan mengenai gambaran pertanian jeruk di Batangmata Sapo. Setelah berhasil dalam swasembada beras pemerintah memberikan perhatian yang lebih dalam pengembangan komoditas holtikultura. Seperti halnya daerah Sulawesi Selatan dalam meningkatkan pertumbuhan ekonominya juga mengembangkan berbagai macam usaha salah satunya dalam bidang holtikultura tersebut. Melalui jenis tanaman jeruk yang dikembangkan di daerah Luwu dan Selayar. Pada tahun 1979 jumlah petani kelapa lebih banyak dibandingkan petani yang membudidayakan jenis tanaman lain . Baru kemudian pada era 1980-an masyarakat di daerah ini banyak yang beralih untuk membudidayakan jeruk karena dianggap lebih menjanjikan hasil yang lebih baik dibandingkan dengan menanam kelapa. Daerah Batangmata Sapo yang mengembangkan pertanian jeruk untuk pertama kalinya terdapat di sebuah kampung yang bernama Tamallua. Bertani jeruk tidak selamanya berjalan mulus penyakit dan musim juga merupakan kendala yang dialami oleh para petani saat sekarang ini. Kajian ini menarik untuk diteliti karena Batangmata Sapo merupakan sentra produksi jeruk di Kabupaten Kepulauan Selayar belum ada peneliti yang mengkaji secara spesifik . Penelitian ini adalah penelitian kualitatif dengan pendekatan analisis deskriptif, yang terdiri atas beberapa tahapan yakni: (1) Heuristik, dengan melakukan wawancara terhadap beberapa petani jeruk seperti: Makmur, Taris, Muh. Daeng, Harundini. Mengumpulkan arsip di Dinas Pertanian Dan Ketahanan Pangan Kabupaten Kepulauan Selayar, mengenai data-data produksi jeruk di tiap tahunnya Selain itu juga digunakan buku-buku yang terkait dengan pertanian dan tanaman jeruk seperti buku karya Rahmat Rukmana berjudul usaha tani jeruk keprok.(2) Kritik atau proses verifikasi keaslian sumber sejarah. (3) Interpretasi atau penafsiran sumber sejarah, dan (4) Historiografi, yakni tahap penulisan sejarah.
\end{abstract}

\section{Kata Kunci:Jeruk, Petani, Batangmata Sapo}

\begin{abstract}
This paper attempt to provide an explanation of the description of orange farming in Batangmata Sapo. After having succes in rice self-sufficiency the government is giving more attention in the development of horticultural commodities. As well as South Sulawesi region that increasing the economic growth and also develops a wide variety of business, one of them in the field of horticulture. Through the type of orange plant developed in the Luwu and Selayar areas. In 1979's the coconut farmers was much higher more than of other cultivators. In the 1980's people in this area are turning to cultivate oranges because that is considered more promising a better result than planting coconut. The Batangmata Sapo area that development the oranges agriculture for the first time was in a village called Tamallua. Being farmed oranges is not always pan out, the disease and the season become a obstacle to farmers right now. This study is interesting to be studied because Batangmata Sapo is a center of orange production in Selayar Islands District because there are no one of researcher that looked at specifically. This research is a qualitative research with descriptive
\end{abstract}


analysis approach, which consist of several stages namely: (1) Heuristic, by interviewing some orange farmers such: Makmur, Taris, Muh. Daeng, Harundini. The archives collection at the Agriculture Department and Food Security of the Selayar Islands Regency, regarding orange production data in each year and also used a books that related to agriculture andorange crops such as Rahmat Rukmana's book entitled Tangerine farming (2) Criticism or the process of verifying the authenticity of historical sources. (3) Interpretation or interpretation of historical sources, and (4) Historiography, is the stage of historical writing.

\section{Keywords: Orange, Farmers, Batangmata Sapo}

\section{A. Pendahuluan}

Indonesia merupakan negara agraris yang memiliki daerah pertanian, usaha pertanian dan budidaya tanaman serta ternak menjadi kebudayaan yang diturunkan dari generasi ke generasi. Indonesia melaksanakan pembangunan di segala bidang pembangunan yang berlandaskan pada Garis-garis Besar Haluan Negara (GBHN). Pada setiap tahap pembangunan tersebut, pembangunan ekonomi pertanian merupakan bagian yang diprioritaskan karena Indonesia adalah negara agraris yang harus melihat pertanian sebagai potensi dominan. (Hernanto, 1993)

Pertanian Indonesia adalah pertanian tropika, karena sebagian besar daerahnya berada di daerah tropis yang langsung dipengaruhi oleh garis khatulistiwa yang memotong Indonesia menjadi dua. Walaupun pada kenyataannya tanamantanaman pertanian yang ada di Indonesia yang memiliki berbagai iklim di tiap daerah yang berbeda seperti halnya pada tanaman iklim sub-tropik dan tanaman iklim sedang seperti kopi, kina, sayur-sayuran dan buahbuahan. (Mubyarto, 1989)

Salah satu komoditas buah-buahan yang potensial dikembangkan secara komersial adalah jeruk. Nilai ekonomi jeruk cukup tinggi dan merupakan pelengkap utama dalam menunjang gizi keluarga. Di antara jenis jeruk komersial, jeruk keprok mempunyai potensi ekonomi cukup tinggi. Buah jeruk keprok telah menjadi mata dagang di pasar dalam negeri dan luar negeri (dunia).
Jeruk keprok yang pertama kali populer adalah jeruk mandarin atau disebut jeruk we. Pada perkembangan selanjutnya jeruk keprok ditanam di berbagai negara, sehingga saat ini banyak varietas jeruk spesifik lokalita yang mempunyai karakteristik dan kualitas buah berdasarkan kondisi agroekologi daerah penanaman. Agribisnis jeruk keprok berkembang di berbagai negara diantaranya RRC kemudian masuk ke Indonesia. (Rukmana \& Oesman, 2008)

Ditinjau dari aspek sejarahnya, jeruk dikenal berasal dari beberapa negara yang ada di Asia yaitu India, Cina Selatan, dan beberapa jenis dari Florida, Australia Utara, dan Kaledonia. Jeruk besar dapat dijumpai di Kalimantan dan Malaysia. Namun kini tanaman jeruk dapat dijumpai di seluruh dunia. (Sunarjono, 2008)

Jeruk memerlukan syarat tumbuh tertentu meliputi ketinggian tempat, jenis tanah, PH, dan iklim yang terdiri dari suhu kelembapan, curah hujan dan lain-lain. Memang jeruk bisa ditanam dimana saja, tetapi hasilnya tidak akan memuaskan seperti bila ditanam di lokasi yang sesuai syarat tumbuhnya. (Tim Penulis PS, 2007)

Salah satu daerah di Indonesia yang membudidayakan jeruk adalah daerah Kabupaten Kepulauan Selayar yang merupakan salah satu kabupaten di Sulawesi Selatan. Kabupaten Kepulauan Selayar adalah Kabupaten yang terletak di Sulawesi Selatan yang memiliki 11 kecamatan. 5 kecamatan terletak di pulau utama dan 6 kecamatan terletak di luar 
pulau utama. Kabupaten Kepulauan Selayar memiliki luas wilayah daratan seluas $1.357,15 \mathrm{Km}^{2}$ dengan luas wilayah terluas berada di Kecamatan Bontosikuyu dan luas wilayah terkecil berada di Kecamatan Benteng. Dengan kondisi geografis yang ada, Kecamatan Pasilambena merupakan kecamatan terjauh yang berjarak $+193 \mathrm{Km}$ dari ibukota kabupaten. (Badan Pusat Statistik, 2016)

Batangmata Sapo merupakan salah satu kelurahan yang ada di Kecamatan Bontomatene, Kabupaten Kepulauan Selayar. Batangmata Sapo memiliki kondisi geografis yang berada di daerah dataran tinggi yang menyimpan potensi alam yang subur seperti daerah perkebunan kelapa, mangga, jeruk dan mente. Masyarakat Batangmata Sapo merupakan penduduk asli Selayar dan hidup rukun berdampingan. Dengan kondisi geografis yang baik membuat masyarakat Batangmata Sapo memanfaatkan lahan perkebunannya dengan menanam jenis tanaman yang memiliki daya jual untuk memenuhi kebutuhan ekonomi mereka.

Berdasarkan hasil wawancara dengan Bapak Dg.Sibeta menuturkan pada tahun 1979 jumlah petani jeruk di Batangmata Sapo adalah tiga puluh orang yang tergabung dalam kelompok usaha tani yang didirikan oleh masyarakat setempat dengan nama A'Munte Sibatu. Jumlah produksi per tahunnya adalah bisa mencapai kurang lebih 2.500-5000 buah per pohon. Namun jumlah tersebut tidak menentu setiap tahunnya, tergantung dari faktor musim dan cuaca yang tidak menentu. Hasil produksinya dijadikan sebagai bahan konsumsi pribadi dan adapula yang dijual di Pasar Benteng. (Sibeta, 2018)

Jeruk Selayar merupakan salah satu komoditas holtikultura unggulan. Tanaman ini sudah lama diusahakan oleh petani dengan keuntungan usaha tani yang cukup tinggi. Jeruk keprok Selayar merupakan komoditas primadona bagi petani setempat. Pertanaman jeruk tersebar di daratan Pulau Selayar terutama di Kecamatan Bontoharu, Bontomatene, dan Bontosikuyu. Oleh karena itu, pemerintah daerah setempat menetapkan jeruk sebagai salah satu komoditas andalan dan dikembangkan dalam skala agribisnis. (Kartodirjo, 2014)

Penelitian ini menjadi menarik karena kajian mengenai petani jeruk di Selayar belum pernah ditulis oleh peneliti lain khususnya petani jeruk yang ada di Kelurahan Batangmata Sapo. Maka dari itu peneliti berusaha untuk menghadirkan kajian ini dalam bentuk karya sejarah berupa skripsi dengan judul Petani Jeruk di Kelurahan Batangmata Sapo Kabupaten Kepulauan Selayar (1979-2017). Hasil penulisan ini diharapkan dapat dijadikan referensi untuk penulisan selajutnya dan sebagai bahan bacaan civitas akademika jurusan pendidikan sejarah Universitas Negeri Makassar.

\section{B. Metode Penelitian}

Penelitian ini merupakan penelitian sejarah yang bersifat deskriptif analitis dengan tujuan untuk menemukan dan mendeskripsikan secara analitis serta menginterpretasikan terkait dengan Petani Jeruk di Kelurahan Batangmata Sapo Kabupaten Kepulauan Selayar (1979-2017). Penelitian ini diartikan untuk meneliti, mengungkapkan serta menjelaskan peristiwa yang telah terjadi di masa lampau sehingga jelas diarahkan kepada metode penelitian sejarah yang bersifat kualitatif. Penelitian ini termasuk dalam kajian sejarah agraria karena dalam penelitian ini akan dijelaskan tentang bagaimana latar belakang petani jeruk, lahan yang digunakan dalam proses pertanian jeruk, perkembangan pertanian jeruk dan dampak sosial ekonomi petani jeruk di Kelurahan Batangmata Sapo Kabupaten Kepulauan Selayar tahun 1979-2017.

Berdasarkan uraian tersebut diatas dapat disimpulkan bahwa metode sejarah merupakan cara atau tehknik dalam merekontruksi peristiwa masa lalu, melalui empat tahapan kerja yaitu heuristik (pengumpulan sumber), Kritik sumber (eksternal/bahan dan internal/isi), 
Interpretasi (penafsiran) dan historiografi (penulisan sejarah).

\section{Heuristik}

Pengumpulan sumber atau dalam kajian sejarah atau lebih dikenal dengan istilah heuristik. Heuristik merupakan proses pencarian atau pengumpulan sumber-sumber yang akan digunakan untuk merekontruksi sejarah.. Sumber sejarah dibedakan atas sumber tulisan, lisan dan benda sumber primer yang tertulis dalam sejarah umumnya berupa dokumen (arsip). (Hamid \& Madjid, 2011). Dalam melakukan pengumpulan sumber, penulis menempuh dua cara yaitu penelitian pustaka dan penelitian lapangan.

\section{Kritik Sumber}

Kritik sumber dilakukan untuk menentukan otensitas dan kredibilitas sumber sejarah. Semua sumber sejarah yang telah dikumpulkan terlebih dahulu diverifikasi sebelum digunakan. Sebab tidak semua sumber dapat langsung digunakan dalam penulisan. Adapun aspek yang dikritik adalah keaslian sumber dan tingkat kebenaran informasi.

Kritik sumber yang dilakukan dalam penelitian ini yaitu memilah sumber sumber yang telah didapat baik itu berupa buku atau dokumen maupun wawancara kepada petani jeruk mengenai bagaimana proses pertanian jeruk di Batangmata Sapo sesuai dengan fakta yang ada di lapangan.

\section{Interpretasi}

Interpretasi adalah proses pemaknaan fakta sejarah. Dalam interpretasi, terdapat dua poin penting, yaitu sintesis (menyatukan) dan analisis (menguraikan). Fakta-fakta sejarah dapat diuraikan dan disatukan sehingga mempunyai makna yang berkaitan satu sama lainnya. (Tim Pengajar Jurusan Pendidikan Sejarah, 2013) Tahapan ini merupakan tahapan setelah kritik sumber. Sumber-sumber sejarah yang telah didapatkan sifatnya masih bisu. Oleh karena itu, Maka seorang peneliti akan menyusun fakta-fakta sejarah yang dapat dibuktikan kebenarannya dalam hal ini sumber-sumber yang telah didapat mengenai petani jeruk di Batangmata Sapo dilakukan penyusunan sesuai dengan tahapan-tahapan fakta yang ada.

\section{Historiografi}

Dalam kaitannya dengan historiografi yaitu proses penulisan sejarah banyak aspek yang berkaitan didalamnya. Menurut Hexter, proses pengumpulan bukti-bukti sejarah, pengeditan sumber sejarah, pengunaan pemikiran dan imajinasi sejarah, dan sebagainya merupakan suatu proses yang tidak dapat dipisahkan dengan historiografi. (Hariyono, 1995)

Penulisan sejarah merupakan proses penjelasan dari semua kegiatan dalam proses penelitian sejarah. Pada tahap ini peneliti mencoba untuk mengambarkan hasil penelitiannya. Dalam hal ini pada penelitian tentang Petani Jeruk di Kelurahan Batangmata Sapo Kabupaten Selayar pada tahun (1979-2017). Peneliti mencoba mengambarkan bagaimana latar belakang Petani Jeruk, Perkembangan dan dampak pada bidang sosial-ekonomi di Batangmata Sapo.

\section{Tinjauan Penelitian \\ 1. Keadaan Geografis}

Mengetahui keadaan geografis suatu wilayah dan masyarakat yang akan dijadikan sebagai obyek dalam sebuah penelitian sangatlah penting untuk menentukan karakteristik masyarakat, mata pencaharian dan budayanya (Fachruddin, 2016). Peranan sejarah ditentukan oleh factor geografis. Secara mudah dapat dikatakan bahwa kalau tidak ada bumi, sudah tentu tidak ada sejarahnya (Mahadir, 2013).

Kabupaten Kepulauan Selayar adalah daerah kepulauan yang terletak diantara 5042'-7035' Lintang Selatan dan 120015'122030' Bujur Timur. Terdapat 130 pulau besar dan kecil baik berpenghuni ataupun belum di wilayah ini. Luas wilayah daratan Selayar mencapai 1.357,03 Km2, sementara kawasan lautnya sebesar 9.146,66 Km2. (Maro \& dkk, 2017) Secara topografis, fisiografi Kabupaten Kepulauan Selayar bervariasi terbagi menjadi 3 satuan morfologi, yaitu satuan morfologi daratan 
alluvial pantai, satuan morfologi perbukitan dan bergelombang dan satuan morfologi perbukitan dengan lereng terjal. (Maro \& $\mathrm{dkk}, 2017)$

Tabel 1.1 Perbandingan Kecamatan Tahun 1979 dan 2017

\begin{tabular}{|l|l|l|}
\hline NO & $\begin{array}{l}\text { Kecamatan } \\
\text { Tahun 1979 }\end{array}$ & $\begin{array}{l}\text { Kecamatan } \\
\text { Tahun 2017 }\end{array}$ \\
\hline 1 & Bontomate'ne & Bontomate'ne \\
\hline 2 & Bontoharu & Bontoharu \\
\hline 3 & Benteng & Benteng \\
\hline 4 & Pasimasunggu & Pasimasunggu \\
\hline 5 & Pasimarannu & Pasimarannu \\
\hline 6 & - & $\begin{array}{l}\text { Pasimasunggu } \\
\text { Timur }\end{array}$ \\
\hline 7 & - & Bontomanai \\
\hline 8 & - & Bontosikuyu \\
\hline 9 & - & Takabonerate \\
\hline 10 & - & Pasilambena \\
\hline 11 & - & Buki \\
\hline
\end{tabular}

Sumber: BPS. Kabupaten Dati II Selayar Dalam Angka Tahun 1980 dan BPS Kabupaten Kepulauan Selayar Dalam Angka 2017..

Kabupaten Kepulauan Selayar pada tahun 1979 memliki 5 kecamatan yaitu Kecamatan Bontomatene, Bontoharu, Bontosikuyu,Pasimasunggu, Pasimarannu. (Badan Pusat Statistik, 1980) Sementara pada tahun 2017 wilayah administratif Kabupaten Kepulauan Selayar bertambah menjadi 11 kecamatan, dengan enam tambahan kecamatan baru, yakni Pasimasunngu Timur, Bontomanai, Bontosikuyu, Takabonerate, Pasilambena, dan Buki.

Batangmata Sapo merupakan salah satu wilayah yang termasuk dalam administratif Kecamatan Bontomatene pada tahun 1979. Dimana Batangmata Sapo dahulu berbentuk sebagai lingkungan yang merupakan wilayah administratif dari Kelurahan Batangmata. Memasuki tahun 1995 Batangmata Sapo yang dulunya merupakan sebuah lingkungan berubah status menjadi kelurahan (Rosdiawati, 2018) karena telah memenuhi persyaratan seperti halnya: luas wilayah, jumlah penduduk, sarana dan prasarana pemerintahan, potensi ekonomi dan kondisi sosial budaya masyarakat. (Jamaluddin, 2015)

Kelurahan Batangmata Sapo merupakan kelurahan kedua di Kecamatan Bontomatene. Kelurahan ini terdapat di daerah pegunungan sebelah timur Kelurahan Batangmata. Pusat perkampungan penduduk berada di ketinggian 280 meter di atas permukaan laut. Dibagian timur kelurahan ini terdapat hutan dan semak belukar serta perkebunan buah-buahan, cengkeh dan tanaman tahunan lainnya. Luas Kelurahan Batangmata Sapo adalah 12,45 $\mathrm{Km}^{2}$.

Adapun batas wilayah dari Batangmata Sapo pada saat berstatus lingkungan yang tergabung dalam wilayah administratif Kelurahan Batangmata dari tahun 19791994 yaitu:

1. Sebelah Utara Berbatasan dengan Desa Tanete

2. Sebelah Selatan Berbatasan dengan Desa Buki

3. Sebelah Timur Berbatasan dengan Desa Onto

4. Sebelah Barat Berbatasan dengan Laut Flores

\section{B . Keadaan Demografis}

Keadaan demografis senantiasa berhubungan dengan jumlah kependudukan yang memiliki peranan kontributif terhadap ruang gerak dan dinamika Kelurahan Batangmata Sapo baik dari aspek sosial, ekonomi dan budayanya (Mantra, 2000)

Penduduk merupakan salah satu elemen penting yang memiliki pengaruh penting terhadap perkembangan pembangunan di suatu daerah. Hal ini dikarenakan penduduk merupakan pelaksana (Subyek) dari pembangunan sekaligus sebagai sasaran (Obyek) pembangunan itu sendiri. Jumlah penduduk di suatu daerah dapat meningkat akibat tingginya angka kelahiran ditambah masuknya penduduk yang berasal dari daerah lain (migrasi). (Mahadir, 2013)

Batangmata Sapo pada tahun 1979 masih berstatus sebagai lingkungan dalam 
wilayah administratif Kelurahan Batangmata. Data kependudukan yang terkait dengan daerah ini dapat dilihat pada buku tahunan yang diterbitkan oleh Badan Pusat Statistik Kabupaten Kepulauan Selayar pada tahun 1980. Pada tahun tersebut jumlah penduduk Kelurahan Batangmata adalah 5.571 jiwa. Dari jumlah tersebut 2.657 jiwa adalah penduduk lakilaki, sementara penduduk perempuan adalah 2.914 jiwa. (Badan Pusat Statistik, 1980) Sementara itu pada tahun 2017 jumlah penduduk Kelurahan Batangmata Sapo yakni 983 penduduk. (Kantor Kelurahan Batangmata Sapo, 2017).

\section{Keadaan Sosial-Ekonomi}

\section{Stratifikasi Sosial}

Stratifikasi merupakan simbol yang berfungsi untuk memberikan dan memperlihatkan serta memberi tahu atas status yang diduduki seseorang. (Jamaluddin, 2015) Stratifikasi sosial masyarakat Selayar pada umumnya berdasarkan keturunan dan terdiri atas tiga lapisan yakni: $O p u$ (Bangsawan), $T u$ Maradeka/ tau biasa/ tau samara (orang biasa) dan terakhir adalah Ata/pasomposompo poke (hamba/budak/keturunan pengawal opu atau karaeng yang bersenjatakan poke/tombak). (Maro \& dkk, 2017)

Stratifikasi sosial seperti di atas, pada dasarnya sama dengan pelapisan sosial masyarakat lainnya di Sulawesi Selatan. Sistem stratifikasi sosial tersebut memegang peranan penting dalam kehidupan masyarakat Selayar begitupun juga di daerah Batangmata Sapo stratifikasi sosial tersebut juga berlaku pada masa lampau. (Maro \& dkk, 2017) Seiring berjalannya waktu jelas bahwa hal mengenai pelapisan sosial masyarakat telah mengalami perubahan, dimana perubahan tersebut dilatarbelakangi oleh pendidikan, harta benda/kekayaan, dan semakin terbuka luasnya media pergaulan antar berbagai lapisan masyarakat. (Maro \& dkk, 2017)

\section{Sistem Kekerabatan}

Sistem kekerabatan di kalangan masyarakat Selayar dikenal dengan istilah Passibijaang. Sistem ini masih tetap dipertahankan dan dijunjung tinggi hingga hari ini. Sistem tersebut sama dengan apa yang dikenal dalam istilah Makassar (Passibijaeng), dan Bugis (ada'asseajingeng).

Sistem kekerabatan yang berlaku bagi masyarakat Selayar adalah sistem bilateral (Parental). Berdasarkan sistem kekeluargaan bilateral, hubungan kekeluargaan seseorang dapat ditelusuri melalui dua jalur, yakni hubungan kekeluargaan dari garis keturunan ayah maupun ibu.

Kelompok kekerabatan tersebut juga terbentuk oleh dua pola, yakni pola kelahiran dan pola perkawinan. Terminologi kerabat dalam bahasa Selayar disebut bija, yang dapat digolongkan menjadi dua bagian yakni bija pammankan dan bija passianakang. Kategori bija pertama adalah kelompok kekerabatan yang terbentuk melalui jalur kelahiran dan bija kedua terbentuk melalui jalur perkawinan.

Kekerabatan dalam unit sosial terkecil dinamakan bija pammanakang sibatu sapo, yakni mencakup keluarga yang tinggal dalam satu rumah. Makna tinggal dalam satu rumah atau tinggal bersama dalam konsep ini yakni setiap individu dalam satu rumah tangga merupakan satu kesatuan sosial, baik dalam aspek ekonomi, budaya dan agama.

Hal lainnya yang menarik dari sistem kekerabatan dalam masyarakat Selayar, yakni sejak dahulu kala mereka memiliki prinsip kesetiaan yang dijunjung tinggi. Karena itu dengan beberapa pengecualian semua pasangan yang telah melangsungkan akad nikah (memiliki ikatan perkawinan) sepakat untuk setia hingga akhir hayat. (Maro \& dkk, 2017)

\section{Mata Pencaharian}

Mata pencaharian merupakan aktifitas yang dilakukan oleh masyarakat dalam rangka pemenuhan kebutuhan hidup sehari-hari. Kondisi geografis Batangmata Sapo yang berupa dataran tinggi, 
berpengaruh pada jenis pekerjaan yang dilakukan oleh masyarakatnya. Di daerah ini, mayoritas masyarakatnya bekerja sebagai petani. Dominasi sektor pertanian sebagai mata pencaharian penduduk dapat terlihat nyata di daerah pedesaan.

Hingga saat ini, lapangan kerja yang tersedia di daerah pedesaan masih di dominasi oleh sektor usaha bidang pertanian. Kegiatan usaha ekonomi produktif di daerah pedesaan masih sangat terbatas ragam dan jumlahnya yang masih cenderung terpaku pada bidang pertanian (agribisnis). Dengan beberapa jenis tanaman yang dibudidayakan seperti jeruk, kelapa, jambu mete, dan lain-lain. (Jamaluddin, 2015)

Pada tahun 1979 jumlah petani kelapa lebih banyak dibandingkan petani yang membudidayakan jenis tanaman lain . Baru kemudian pada era 1980-an masyarakat di daerah ini banyak yang beralih untuk membudidayakan jeruk karena dianggap lebih menjanjikan hasil yang lebih baik dibandingkan dengan menanam kelapa.

\section{Pembahasan}

\section{Awal Mula Pertanian Jeruk di Kelurahan Batangmata Sapo}

Setelah berhasil dalam swasembada beras pemerintah memberikan perhatian yang lebih dalam pengembangan komoditas holtikultura. Seperti halnya daerah Sulawesi Selatan dalam meningkatkan pertumbuhan ekonominya juga mengembangkan berbagai macam usaha salah satunya dalam bidang holtikultura tersebut. Melalui jenis tanaman jeruk yang dikembangkan di daerah Luwu dan Selayar. (Saptana \& Noekman, 2016)

Khusus untuk daerah Selayar, tanaman jeruk pertama kali diperkenalkan oleh para pedagang Selayar yang melakukan kontak dagang dengan pedagang dari daerah Bali dan Ambon. Tidak ada catatan pasti yang menyebutkan siapa orang yang pertama kali membawa bibit jeruk tersebut masuk ke Selayar. Namun menurut narasumber tanaman jeruk sudah ada sebelum Jepang masuk ke Selayar. Daerah yang pertama kali mendapatkan bibit tanaman jeruk di kabupaten ini adalah daerah Laiyolo, yang berada di pantai bagian selatan pulau Selayar.

Meskipun daerah Laiyolo yang pertama kali mengenal jenis tanaman jeruk dari para pedagang kopra, namun pada perkembangan berikutnya daerah ini tidak menjadi sentra budidaya jeruk karena kondisi geografis dan tanahnya yang tidak cocok untuk pertanian jeruk. Sebagaimana dijelaskan oleh narasumber berikut

"jika dilihat dari sejarahnya jeruk pertama kali masuk di Selayar dibawa oleh para pedagang dari Bali. Pertama kali menanam jeruk di daerah Laiyolo namun tidak berbuah akan tetapi setelah dicoba di tanam di daerah Batangmata Sapo itu sudah berbuah dan banyak hasilnya." (Makmur, 2018)

Batangmata Sapo sebagai salah satu daerah yang berada di ketinggian 280 meter memiliki kondisi tanah yang cocok untuk pengembangan tanaman jeruk, sehingga menjadikan daerah ini sebagai penghasil utama jeruk di Kabupaten Kepulauan Selayar. Hal ini yang mendasari masyarakat Batangmata Sapo mengalihkan sebagian lahannya yang dahulu digunakan untuk bertani kelapa menjadi lahan untuk menanam jeruk

Daerah Batangmata Sapo yang mengembangkan pertanian jeruk untuk pertama kalinya terdapat di sebuah kampung yang bernama Tamallua. Kampung ini tepatnya berada di daerah perbatasan Desa Onto dan Kelurahan Batangmata Sapo bagian selatan. Sebagaimana yang dikemukakan oleh narasumber berikut.

"Jeruk sebelumnya sudah ada jauh sebelum Jepang, dikarnakan orang Jepang memakan jeruk bersama dengan kulitnya. Tetapi untuk daerah Batangmata Sapo yang pertama kali menanam jeruk bernama Dg.Sakkak mulai menanam di daerah Tamallua pada tahun 1940 dan pada tahun 1942 sudah ada jeruk yang dibawa keluar daerah Batangmata Sapo. Nanti memasuki tahun 1980 barulah jeruk 
mulai dikembangkan.” (Harundini, 2018)

Narasumber pada kutipan diatas menjelaskan bahwa Jeruk di daerah Batangmata Sapo tepatnya di daerah Tamallua, sudah ada sebelum masuknya Jepang di Selayar. Orang yang pertama kali menanam jeruk bernama Dg. Sakkak pada tahun 1940 dan pada tahun 1942 diketahui sudah ada jeruk yang dibawa keluar daerah Batangmata Sapo. Namun pada saat itu, jeruk belumlah dikembangkan secara besarbesaran untuk dipasarkan secara luas, namun hanya untuk konsumsi pribadi saja dikalangan keluarga Dg. Sakkak.

\section{Lahan Pertanian Jeruk di Kelurahan Batangmata Sapo}

Lahan adalah tanah yang digunakan untuk usaha pertanian. Jadi tidak semua tanah merupakan lahan pertanian dan sebaliknya semua lahan pertanian adalah tanah. Istilah penggunaan lahan berbeda dengan penggunaan tanah. (Daniel, 2002) Penggunaan lahan di perdesaan umumnya terdiri atas penggunaan lahan pertanian, perkebunan dan lain-lain, (Jamaluddin, 2015) sedangkan penggunaan tanah merupakan kecocokan anatara jenis tanah dengan tanaman yang akan ditanam.

Jenis tanah perlu menjadi perhatian dalam proses usaha tani dan usaha pertanian. Karena jenis tanah akan mengarahkan petani kepada pilihan komoditas yang sesuai, pilihan teknologi (misalnya alat sortir buah jeruk atau yang dikenal dengan istilah grading), serta pilihan metode pengolahan tanah (tradisional atau modern). Keadaaan dan jenis tanah akan memberikan atau mengarahkan petani pada kebijaksanaan atau pilihan penggunaan pupuk dan pemupukan. (Daniel, 2002)

Sama seperti tanah, tanaman juga mempunyai sifat-sifat tertentu. Ada tanaman yang dapat tumbuh pada sembarang jenis tanah. Tetapi pada umumnya tiap jenis tanaman, bahkan tiap varietas tanaman menghendaki jenis tanah sendiri. Ketidakcocokan jenis tanah dan jenis tanaman akan berpengaruh besar pada pertumbuhan tanaman yang berakibat langsung terhadap hasil dan produksi tanaman itu sendiri. (Daniel, 2002)

Kondisi tanah di daerah Batangmata Sapo yang cocok untuk pertanian jeruk juga diungkapkan oleh narasumber berikut:

"Jika dilihat dari kondisi tanah yang ada di wilayah Batangmata Sapo dengan tanah bebatuan dan gersang tidak cocok untuk ditanami kelapa dan lebih cocok untuk ditanami jeruk." (Makmur, 2018)

Jika dilihat dari pendapat narasumber diatas, tanah di Batangmata Sapo memang jenis tanah yang lebih cocok untuk ditanami jeruk dibandingkan dengan tanaman lain seperti kelapa, karena jenis tanah di daerah tersebut adalah jenis tanah bebatuan.

Istilah ilmiah untuk jenis tanah ini adalah Litosol, yang merupakan jenis tanah berbatu-batu dengan lapisan tanah yang tidak begitu tebal. Penampangnya besar dan berbentuk kerikil, pasir, atau batu-batuan kecil, karena sedikit sekali mengalami perubahan struktur atau profil dari batuan asal. (Sasrawan, 2013)

Karakteristik tanah yang seperti ini, menyebabkan masyarakat Batangmata Sapo memilih untuk menggunakan lahan mereka dalam usaha pertanian jeruk. Lahan yang digunakan untuk pertanian jeruk di daerah ini dapat dilihat pada tabel berikut:

Tabel 3.1. Hasil Jeruk di Kelurahan Batangmata Sapo

\begin{tabular}{|c|c|c|}
\hline Tahun & $\begin{array}{l}\text { Luas } \\
\text { Tanaman }\end{array}$ & $\begin{array}{l}\text { Hasil Tanaman } \\
\text { (berbuah) }\end{array}$ \\
\hline 2010 & $135 \mathrm{Ha}$ & $40 \mathrm{Ton} / \mathrm{Ha}$ \\
\hline 2011 & $142 \mathrm{Ha}$ & 40 Ton/Ha \\
\hline 2012 & $170 \mathrm{Ha}$ & $40 \mathrm{Ton} / \mathrm{Ha}$ \\
\hline 2013 & $250 \mathrm{Ha}$ & 3,75 Ton/Ha \\
\hline 2014 & $250 \mathrm{Ha}$ & 3,75 Ton/Ha \\
\hline 2015 & $250 \mathrm{Ha}$ & 3,75 Ton/Ha \\
\hline 2016 & $250 \mathrm{Ha}$ & 3,75 Ton/Ha \\
\hline 2017 & $250 \mathrm{Ha}$ & 3,75 Ton/Ha \\
\hline
\end{tabular}


Dilihat dari data tabel diatas dapat diketahui bahwa bahwa pada tahun 2010 luas areal tanaman jeruk adalah $135 \mathrm{Ha}$, dengan hasil tanaman 40 ton/Ha. Luas areal tanaman terus bertambah hingga tahun 2013 mencapai luas $250 \mathrm{Ha}$ dan areal ini tidak mengalami perubahan hingga tahun 2017. Meskipun demikian bertambahnya luas areal tanaman tidak berbanding lurus dengan hasil tanaman yang berbuah. Hal ini dapat dilihat pada tabel tersebut bahwa sejak tahun 2013 hasil tanaman menurun drastis dari 40 ton menjadi 3,75 ton/Ha. Hasil ini tetap sama hingga tahun 2017. (Kantor Kelurahan Batangmata Sapo, 2010-2017)

Menurunnya hasil produksi tanaman jeruk diakibatkan oleh penyakit yang menyerang tanaman jeruk yakni penyakit Blendok dan penyakit Busa. Hal serupa pernah terjadi pada tahun 1994 dan 1997 luas pertanaman jeruk keprok selayar mengalami penurunan produktivitas.

\section{a. Sistem Kepemilikan Tanah}

Sistem kepemilikan tanah dan penguasaan tanah dari masing-masing waktu dan tempat secara fundamental memiliki ciri serta kekhasan tersendiri berdasarkan kesepakatan sosial atau bentukan masyarakat. Timbulnya kecenderungan masing-masing komunitas mempertahankan nilai-nilai budaya (tradisi) tersebut termasuk sistem kepemilikan dan penguasaan tanah, pada prinsipnya disebabkan oleh pengaruh lingkungan. (Ahmadin, 2013)

Luas penguasaan lahan pertanian merupakan sesuatu yang sangat penting dalam proses produksi ataupun usaha tani dan usaha pertanian. Dalam usaha tani misalnya pemilikan atau penguasaan lahan sempit sudah pasti kurang efisien dibanding lahan yang lebih luas. Semakin sempit lahan usaha, semakin tidak efisien usaha tani yang dilakukan. (Daniel, 2002)

Adapun kepemilikan tanah yang dikelola untuk pertanian jeruk di daerah Batangmata Sapo, terbagi dalam tiga jenis, yakni tanah yang dikelola langsung oleh pemiliknya, ada tanah yang di kelola oleh petani penggarap yang tidak memiliki lahan sendiri, dan adapula tanah yang diwariskan secara turun temurun. (Daniel, 2002)

\section{b. Sistem Bagi Hasil}

Sistem bagi hasil memiliki tampilan yang berbeda sebagaimana perkembangan agraria secara umum dari masing-masing tempat dan waktu. Setiap tempat baik itu dalam lingkup lokal maupun regional, kondisinya akan berbeda berdasrkan tradisi masyarakat yang bersangkutan dan tingkat pemahamnya terhadap sektor ini.

Demikian pula waktu akan sangat berpengaruh secara korelatif terhadap kondisi agrarian termasuk sistem bagi hasil yang didasarkan pada tingkat penggunaan teknologi. Pada mayarakat agraris yang masih tradisional umpamanya, bagi hasil yang diterapkan tentu saja berdasarkan sistem berdasarkan yang diberlakukan secara turun-temurun.

Hubungan kerja yang diberlakukan oleh masyarakat Batangmata Sapo itu sendiri juga sama dengan sistim yang berlaku pada masyarakat yang ada di Sulawesi Selatan. Dalam tradisi masyarakat Selayar sendiri dikenal dengan istilah tesan dimana seorang petani menggarap tanah milik orang lain yang aturan bagi hasilnya ditentukan oleh perjanjian lisan dan biasanya yang menjadi patokan waktu pembagian hasil tersebut yakni usia produksi tanah yang ditaami (digarap)

Hubungan kerja dengan sistem tesan ini menunjukkan pola yang bervariasi berdasarkan bentuk kesepakatan dengan menjadi warisan atau kebiasaan pada masyarakat setempat. Adapun sistem bagi hasil yang berlaku di kalangan masyarakat Batangmata Sapo itu sendiri seperti:

1) Sistem bagi hasil dahu rua (bagi dua), yakni pembagian hasil produksi kebun dengan perjanjian bahwa setelah panen masing-masing pemilik tanah dan penggarap memperoleh separoh (seperdua) hasil tersebut.

2) Sistem bagi hasil dahu tallu (bagi tiga), yakni pembagian hasil produksi kebun dengan ketentuan masing-masing pihak 
penggarap memperoleh satu bagian, sementara pemilik lahan dua bagian.

3) Sistem bagi hasil dahu rata (bagi rata), yakni pembagian yang dilakukan oleh pihak pemilik dan penggarap dengan ketentuan bahwa baik hasil maupun lahan setelah diadakan pembagian masing-masing menjadi hak milik kedua belah pihak.

Sistem bagi hasil kategori pertama biasanya berlaku di lingkungan keluarga sendiri. Maksudnya, antara pemilik tanah dan penggarap masih memiliki hubungan kekeluargaan. Sementara itu tipe kedua umumnya berlaku baik dari keluarga maupun diluar keluarga tetapi hal ini berlaku untuk jenis tanaman jangka panjang. (Ahmadin, 2013)

\section{c. Faktor Pendorong dan Penghambat Pertanian Jeruk \\ 1) Faktor Pendorong}

Memang benar bahwa hidup bukan hanya sekedar untuk mencari makan,tetapi harus dipahami pula bahwa tanpa makan manusia tidak dapat hidup. Berkembangnya zaman membuat orangorang tidak lagi mencari kekuatan atau kekuasaan, tetapi yang utama adalah uang sebagai alat tukar dan juga pemenuhan kebutuhan kehidupan (jasmani). (Daniel, 2002)

Maka dari itu seseorang dituntut untuk mengolah sumber daya ekonomi serta sumber daya alam dengan sebaik dan seefisien mungkin untuk mendapatkan tingkat kepuasan yang tinggi. Dalam kehidupan sehari-hari, seseorang akan dihadapkan pada posisi pengambilan keputusan. Begitupun yang terjadi pada kalangan petani dalam penentuan pilihan pemanfaatan sumber daya alam agar bisa menjadi nilai ekonomi untuk penunjang hidup. (Daniel, 2002)

Hal yang demikian juga terjadi dikalangan petani yang ada di daerah Batangmata Sapo dalam menentukan pilihan untuk mengolah sumber daya alam yang ada, selain itu tentunya akan dipengaruhi oleh berbagi faktor untuk dapat memulai sebuah usaha dalam mengolah sumber daya pertanian seperti yang dikemukakan oleh narasumber

"Karena produksi jeruk lebih banyak keuntungannya dibandingkan dengan kelapa, dikarenakan struktur tanah Batangmata Sapo yang memang bebatuan sehingga cocok ditanami jeruk daripada kelapa. Jeruk bisa berbuah tergantung dari pemeliharaanya. Kita lebih banyak memiih menanam jeruk karna jeruk itu sekali panen dapat menghasilkan puluhan juta dibandingkan kelapa. Harga jeruk juga tidak pernah turun, kalo kelapa harganya turun naik kadangkala juga ambruk. Disisi lain kelapa juga ada upah petik lima ribu per pohon dikali banyak, kalo jeruk itu buahnya bisa kita petik sendiri tanpa memakai upah petik”. (Makmur, 2018) Dari hasil wawancara diatas diketahui bahwa masyarakat yang ada di daerah Batangmata Sapo terutama para petani,termotivasi untuk menanam jeruk karena adanya keuntungan yang besar didapatkan dalam sekali panen dibandingkan dengan menanam kelapa sehingga membuat mereka mengalihkan sebagian lahan yang dimiliki untuk menanam jeruk. Jenis buah ini dapat berbuah atau berproduksi banyak tergantung bagaimana cara petani memelihara tanaman tersebut. Selain itu juga karena struktur tanah Batangmata Sapo berupa bebatuan yang ideal dan mampu mengondisikan jeruk dalam keadaan stress sehingga meningkatkan hasil produksi.

Bapak Mansur Taris selaku narasumber yang juga bekerja sebagai petani mengemukakan faktor lain yang mendorong mereka sehingga mau bertani jeruk "pertama adalah pemasaran jeruk yang mudah dan yang kedua hasil serta untung yang didapatkan juga memuaskan”. (Taris, 2018) Apa yang diungkapkan narasumber menunjukkan bahwa faktor pemasaran serta keuntungan yang diperoleh juga berpengaruh pada 
meningkatnya motivasi petani jeruk dalam mengusahakan budi daya tanaman tersebut.

Pemasaran buah jeruk menjadi faktor pendorong masyarakat untuk bertani karena lebih mudah untuk dijual dibandingkan dengan buah kelapa. Dari hasil penjualan ini juga diperoleh keuntungan yang lebih menjanjikan dalam sekali panen, sehingga banyak petani yang sudah memperbaiki taraf perekonomiannya. Petani jeruk yang telah sukses juga menjadi faktor pendorong bertambahnya jumlah masyarakat yang mengalihkan lahannya untuk bertani jeruk sebgaimana yang dikemukakan oleh narasumber berikut."itu dulu yang lamung Dg.Pahallang lakua lamungko ka lohe pangguppaanna”. (Daeng, 2018) Terjemahan: "Itu dulu yang menanam Dg.Pahallang berkata cobalah untuk menanam karna banyak keuntungan yang di dapat”. Narasumber ini menceritakan motivasi awalnya untuk menanam jeruk karna mendapat dorongan dari temannya yang lebih dulu menanam jeruk dan telah merasakan keuntungan yang di dapatkan.

Jadi dapat ditarik kesimpulan bahwa pada umumnya masyarakat Batangmata Sapo memilih untuk bertani jeruk karena faktor-faktor berikut.

a) Struktur tanah daerah Batangmata Sapo yang ideal untuk ditanami jeruk

b) Harga jeruk yang stabil

c) Pemasaran buah jeruk yang dilakukan oleh para petani lebih mudah dbandingkan dengan kelapa

d) Kisah sukses petani yang lebih dahulu menanam jeruk.

\section{2) Faktor Penghambat}

Usaha pertanian yang dilakukan oleh para petani yang ada di daerah Batangmata Sapo tidak selamanya berjalan mulus dari apa yang kita perkirakan sebelumnya. Hal ini dikarenakan adanya beberapa gangguan yang muncul selama proses budi daya tanaman jeruk.

\section{a) Penyakit Pada Tanaman Jeruk}

Salah satu penyakit yang menjangkiti tanaman jeruk adalah penyakit busa, masyarakat Selayar secara umum menyebut penyakit tersebut dengan nama Tua'-tua. Seperti yang dikemukakan oleh narasumber: "Eh faktor penghambatna injo jua hama yang busa ampa riekmi laserangmi muntenjo gelemi bertahan lama ampa rinni lakua tua'-tua' umummi ampa hakle mae lakua tua'-tua'”. (Taris, 2018) Terjemahan: "faktor yang menjadi penghambat itu tadi yang penyakit busa, kalau sudah menyerang tanaman jeruk dipastikan sudah tidak bertahan lama kalau orang sini menyebutnya tua'tua' dan secara umum orang Selayar juga memakai sebutan yang sama”.

Kutipan wawancara narasumber diatas menceritakan mengenai faktor penghambat mereka dalam bertani jeruk yakni karena adanya penyakit busa. Jika penyakit tersebut menyerang tanaman jeruk, para petani bisa dipastikan merugi karena tanaman tidak akan bertahan lama, dan tanaman jeruk sudah tidak dapat berbuah atau berproduksi lagi sehingga pada akhirnya akan mati.

Tanaman yang terkena penyakit ini umumnya mengalami mati ranting secara bertahap dan akhirnya mati. Upaya pengendalian penyakit busa dapat dilakukan dengan sanitasi kebun yang dikombinasikan dengan penggunaan insektisida ataupun fungisida. (Wanti Dewayani; dkk, 2003)

b) Musim

Keberadaan musim penghujan dan musim kemarau sangat berpengaruh pada keberlangsungan pertanian jeruk di Kelurahan Batangmata Sapo. Hal ini dikarenakan pertumbuhan jeruk yang baru ditanam di kebun bergantung pada curah hujan. Jeruk membutuhkan jumlah air yang cukup untuk menjamin pertumbuhannya dengan baik.

Permasalahan yang dihadapi para petani saat ini karena waktu turunnya hujan tidak menentu seperti biasanya. Meskipun pada umumnya musim hujan berlangsung pada bulan Oktober-April tetapi hujan tidak serta merta turun dengan intensitas yang tetap selama periode tersebut. 
Adakalanya hujan tidak turun beberapa minggu sehingga petani harus mengusahakan penyiraman terhadap bibit jeruk yang baru ditanam.

Begitupun sebaliknya pada bulan April-Oktober yang seharusnya musim kemarau tetapi adakalanya hujan masih turun. Sementara itu, pada periode tersebut petani tidak mengharapkan hal yang demikian karena jeruk tidak akan menghasilkan buah yang banyak jika kelebihan air akibat turun hujan.

Kendala musim yang tidak menentu juga dituturkan oleh Arifuddin pada kutipan berikut.

"Musim yang terjadi sekarang ini sudah tidak teratur seperti dulu, sekarang biasanya waktu sudah memasuki musim penghujan tidak turun hujan, walaupun sudah memasuki waktu musim kemarau biasanya turun hujan. Jeruk dipengaruhi oleh keadan cuaca ketika daunnya sudah melengkung membentuk seperti rokok ketika sudah memasuki tiga bulan musim kemarau." (Sibeta, 2018)

Adanya perbedaan musim yang terjadi pada era dulu dan saat sekarang ini dituturkan oleh narasumber yang menjadi kendala bagi para petani dalam menanam jeruk. Pada umumnya musim hujan yang terjadi pada bulan Oktober - April tapi kenyataaan yang terjadi sekarang ini tidak turun hujan begitupun sebaliknya jikalau tiba musim kemarau pada bulan AprilOktober yang harusnya tidak hujan tetapi hujan turun dengan intensitas yang tinggi. Bagi para petani jeruk yang ada di Batangmata Sapo kedua musim ini memiliki manfaat.

\section{E. Kesimpulan}

Batangmata Sapo sebagai salah satu daerah yang berada di ketinggian 280 meter memiliki kondisi tanah yang cocok untuk pengembangan tanaman jeruk. Kondisi tanah di daerah ini dengan struktur bebatuan memungkinkan tanaman jeruk untuk berbuah dengan baik.pada umumnya masyarakat Batangmata Sapo memilih untuk bertani jeruk karena faktor-faktor berikut.Struktur tanah daerah Batangmata Sapo yang ideal untuk ditanami jeruk Harga jeruk yang stabil Pemasaran buah jeruk yang dilakukan oleh para petani lebih mudah dbandingkan dengan kelapa Kisah sukses petani yang lebih dahulu menanam jeruk.Usaha pertanian yang dilakukan oleh para petani yang ada di daerah Batangmata Sapo tidak selamanya, berjalan mulus dari apa yang kita perkirakan sebelumnya. Hal ini dikarenakan adanya beberapa gangguan yang muncul selama proses budi daya tanaman jeruk. Adanya perbedaan musim yang terjadi pada era dulu dan saat sekarang ini dituturkan oleh narasumber yang menjadi kendala bagi para petani dalam menanam jeruk.

\section{DAFTAR PUSTAKA}

Ahmadin, 2013. Sejarah Agraria Sebuah Pengantar. Makassar: Rayhan Intermedia.

Arifuddin, 2018. Wawancara Di Batangmata Sapo [Interview] (10 Mei 2018).

Badan Pusat Statistik, 1980. Kabupaten Dati II Selayar Dalam Angka Tahun 1980. Benteng: Badan Pusat Statistik.

Badan Pusat Statistik, 2016. Kabupaten Kepulauan Selayar Dalam Angka. Benteng: BPS Kabupaten Kepulauan Selayar.

Daeng, M., 2018. Wawancara di Batangmata Sapo [Interview] (08 Mei 2018).

Daniel, M., 2002. Pengantar Ekonomi Pertanian. Jakarta: Bumi Aksara.

Fachruddin, 2016. Membangun Otonomi Daerah Memperkuat NKRI. Jakarta: Serat Alam Media.

Hamid, A. R. \& Madjid, M. S., 2011. Pengantar Ilmu Sejarah. Kotamadya Ujung Pandang: Ombak.

Hariyono, 1995. Memepelajari Sejarah Secara Efektif. Malang: Pustaka Jaya. 
Harundini, 2018. Wawancara di Batangmata Sapo [Interview] (10 Mei 2018).

Hernanto, F., 1993. Ilmu Usaha Tani. Jakarta(DKI Jakarta): Penebar Swadaya.

Jamaluddin, A. N., 2015. Sosiologi Perdesaan. Bandung: Penerbit Pustaka Setia.

Kantor Kelurahan Batangmata Sapo, 20102017. Laporan Kelurahan Batangmata Sapo 2010-2017. Batangmata Sapo: Kantor Kelurahan. Kantor Kelurahan Batangmata Sapo, 2017. Profil Kelurahan Batangmata Sapo Tahun 2017. Batangmata Sapo: Kantor Kelurahan Batangmata Sapo.

Kartodirjo, S., 2014. Pemikiran Sejarah dan Perkembangan Historiografi Indonesia. Yogyakarta: Ombak.

Mahadir, 2013. Kampung Mandar di ParePare (Studi di Kelurahan Bumi Harapan Kecamatan Bacukiki Barat: 1955-1992). Makiassar: Skripsi Fakultas Ilmu Sosial Universitas Negeri Makassar.

Makmur, 2018. Wawancara di Batangmata Sapo [Interview] (8 Mei 2018).

Mantra, I. B., 2000. Demografi Umum. Yogyakarta: Pustaka Pelajar.

Maro, M. I. \& dkk, 2017. Sejarah Daerah dan Kearifan Lokal Selayar(Pada Masa Revolusi Kemerdekaan 19451950). Selayar: Pemerintah Kabupaten Kepulauan Selayar Dinas Pendidikan Dan Kebudayaan.

Mubyarto, 1989. Pengantar Ekonomi Pertanian. Jakarta: LP3ES.

Muin, M., 2018. Wawancara du Benteng [Interview] (10 Mei 2018).

Rosdiawati, 2018. Wawancara di Batangmata Sapo [Interview] (12 04 2018).

Rosdiawati \& Hamid, A., 2018. Wawancara [Interview] (08 Mei 2018).
Rukmana, R. \& Oesman, Y. Y., 2008. Usaha Tani Jeruk Keprok. Solo: Pabelan Cerdas Nusantara.

Saptana \& Noekman, K. M., 2016. Kajian Aspek Produksi dan Pemasaran Jeruk Pada Lahan Pasang Surut dan Lahan Kering di Sulawesi Selatan : Studi Kasus di Kabupaten Luwu dan Selayar. E-Jurnal Litbang Pertanian, p. 14.

Sasrawan,

H., 2013. hedisasrawan.blogspot.co.Id. [Online] Available at: hedisasrawan.blogspot.co.Id/2013/06/ tanah-litosol.html?m=1

[Accessed 20 Mei 2018].

Sibeta, D., 2018. Wawaancara Di Batangmata Sapo [Interview] (06 Januari 2018).

Sibeta, D., 2018. Wawancara di Batangmata Sapo [Interview] (06 Januari 2018).

Sjamsuddin, H., 2012. Metodologi Sejarah. Yogyakarta: Ombak.

Sunarjono, H., 2008. Berkebun 21 Jenis Tanaman Buah. Jakarta: Penebar Swadaya.

Taris, M., 2018. Wawancara di Batangmata Sapo [Interview] (08 Mei 2018).

Tim Pengajar Jurusan Pendidikan Sejarah, 2013. Pengantar Ilmu Sejarah. Makassar: Universitas Negeri Makassar.

Tim Penulis PS, 2007. Usaha \& Pembudidayaan Jeruk Siam. Jakarta: Penebar Swadaya.

Wanti Dewayani; dkk, 2003. Jeruk Keprol Selayar dan Upaya Pelestariannya. Jurnal Litbang Pertanian, p. 91.

Wirosuhardjo, K., 1981. DasarDasarDemografi. Jakarta: Fakultas Ekonomi Universitas Indonesia.

Wirosuhardjo, K., 2000. Dasar-Dasar $n$ nDemografi. Jakarta: Fakultas Ekonomi Universitas Indonesia. 